\title{
Incision wound healing activity of free-range chicken (Gallus domesticus) egg white gel in mice
}

\author{
Wahyu Widyaningsih*, Sapto Yuliani, Ayu Wulandari, Rifka Salsabila \\ Faculty of Pharmacy, Universitas Ahmad Dahlan \\ Jl. Prof. Dr. Soepomo, S.H, Warungboto,Umbulharjo, Yogyakarta, Indonesia
}

Submitted: 07-04-2021

Reviewed: 06-06-2021

Accepted: 19-09-2021

\begin{abstract}
Egg whites reportedly exhibit wound healing activities by forming new cell tissues and accelerating damaged cell tissue recovery. This study aimed to determine whether and how egg whites prepared in gel dosage forms healed incision wounds in mice (Mus musculus). The method began with formulating gels by mixing egg whites with Carbopol 940, methylparaben, propylparaben, propylene glycol, triethanolamine, and distilled water. Sixteen mice were divided evenly into four groups, and each was subjected to a $1 \mathrm{~cm}$ long midline dorsal incision. Group I was given $10 \%$ povidone-iodine ointment, group II was gel base, group III was $10 \%$ egg white gel, and group IV was $20 \%$ egg white gel. Based on the test parameters measured during macroscopic observation, namely wound length and healing time, the gel preparations were found to fulfill the physical properties requirements, and incision wounds treated with $10 \%$ and $20 \%$ egg white gels healed in 9 and 12.5 days, respectively. The statistical test revealed a significant difference in woundsize on Day 10 and in healing time between wound treatments with $10 \%$ gel and base gel ( $\mathrm{p}<0.05)$. Therefore, it can be concluded that the $10 \%$ egg white gel is effective in healing cuts in mice as it speeds wound healing and decreases wound size.
\end{abstract}

Keywords: wound healing, egg white gel, incision

\footnotetext{
*Corresponding author:

Wahyu Widyaningsih

Faculty of Pharmacy, Ahmad Dahlan University

Jl. Prof. Dr. Soepomo, SH, Warungboto, Umbulharjo, Yogyakarta, Indonesia

Email: wahyu.widyaningsih@pharm.uad.ac.id
} 


\section{INTRODUCTION}

Wounds are damage or loss of body tissues by factors interfering with the body's protection system. Depending on the cause, they can appear in different shapes: open and closed. An incision is an example of small, thin open wounds usually caused by a sharp cut into the skin (Percival, 2014). Wound healing occurs in three phases: inflammation, proliferation, and remodeling. The inflammatory phase is the body's natural response to injury and begins soon after initial wounding. It is characterized by five classic signs, namely erythema, heat, edema, pain, and loss of function (Yao and Bae, 2013). Meanwhile, the proliferative phase of wound healing (about 3-10 days after wounding) mainly comprises wound surface closure, formation of new granulation tissue, and restoration of vascular tissue. In addition to local fibroblast migration, this phase activates neovascularization and angiogenesis. Regulation of wound healing by cytokines like IFN- and TGFplays a crucial part in synthesizing collagen, fibronectin, and other basic substances required for generating a new matrix of connective tissue to close tissue gap and restore the mechanical strength of the wound (Sorg, 2012). The final phase, commencing after the wound fully closes, is remodeling. The wound regains its tensile strength as collagen fibers break down and reorganize. Also, in this phase, the wound undergoes devascularization and returns to its original state of blood supply (Yao and Bae, 2013).

As is well-known by the public, povidone-iodine is a topical medicine used in wound care. However, the use of most topical antiseptics can interfere with wound healing. Povidone iodide $10 \%$ solution is an effective antiseptic. Nevertheless, this solution is possibly toxic to cells involved in the wound healing process (Danarti et al., 2014). Therefore, it is necessary to seek alternatives for wound treatment.

Chicken egg whites contain albumin, i.e., a relatively inexpensive, readily available animal protein source that is also an efficacious pain reliever. They heal wound through two predictable mechanisms: forming new cell tissues and accelerating damaged cell tissue recovery (Hendriati et al., 2018). According to Purnani (2019), giving an individual 139 grams of egg whites proves $62.5 \%$ effective for healing perineal tears-spontaneous lacerations of the perineum, as indicated by the formation of dry, closed wounds with no signs of infection. Meanwhile, according to (Widjaya, 2016), topical application of gels comprising $40 \%$ egg whites can repair incision wounds on white rat skin (Rattus norvegicus) by speeding the healing time and reducing the number of macrophages. Likewise, (Hendriati et al., 2018) report the efficacy of topical egg whites for depleting macrophages, increasing fibroblast activation and collagen fiber density, and accelerating the healing of seconddegree burns.

Here, egg whites are prepared into gel dosage forms to allow easier use and mask the typical odor of egg whites to be acceptable. This research was intended to study the physical properties of gels formulated from egg whites of free-range chicken and their wound healing activities in mice.

\section{MATERIALS AND METHOD Materials}

The test animals were Swiss Webster male mice aged 8-10 weeks weighing 20-25 g, and the gel ingredients included the white part of free-range chicken eggs bought at a traditional market, Pasar Ngasem, Yogyakarta, Carbopol 940 (Brataco, Indonesia), triethanolamine (TEA) (Brataco), propylene glycol (Brataco), methylparaben (Brataco), propylparaben (Brataco), aquadest, 10\% povidone-iodine ointment (Mundipharma), Topsy ointment (Galenium Pharmasia Laboratories), and ketamine injection (Hameln Pharmaceuticals).

\section{Egg white gel formulation}

To create the free-range chicken egg white gel, a Carbopol solution was first prepared: $6 \mathrm{~g}$ of Carbopol 940 base was dissolved in $100 \mathrm{~mL}$ of warm water, stirred, and allowed to swell. Further, $0.54 \mathrm{~g}$ of methylparaben, $0.06 \mathrm{~g}$ of propylparaben, and $15 \mathrm{~g}$ of propylene glycol were mixed and 
stirred until homogeneous and then poured into the Carbopol solution. The mixture was added with these ingredients successively: water (added little by little), egg white (the weight was according to the concentration), then water until the preparation's final weight was $300 \mathrm{~g}$. Afterward, TEA was added dropwise while stirring slowly until a clear gel was formed.

\section{Evaluation of gel preparation}

Organoleptic Observation

The gel preparation was examined for its organoleptic properties: color, odor, shape, and texture. This test aimed to define the gel according to the color and smell of the compound used. The resultant gel is usually clear in color with a semisolid concentration.

$\mathrm{pH}$ testing

This test determined whether the gel $\mathrm{pH}$ was suitable for topical application, that is, in the range of 4.5-6.5. A gel that is too alkaline can cause dry skin, while too acidic gel can irritate the skin. Here, $\mathrm{pH}$ was measured by dipping the $\mathrm{pH}$ indicator stick into the gel for three seconds (Nurman et al., 2019).

\section{Spreadability testing}

A total of $0.5 \mathrm{~g}$ of the gel sample was placed at the center of a round scaled glass plate. Then, an unscaled glass was placed on top of it, added with a $100 \mathrm{~g}$ weight, and allowed to sit for 1 minute. The diameter of the gel spread was measured and recorded (Nurman et al., 2019).

\section{Adhesion testing}

The gel was smeared on an area of $2 \times 2 \mathrm{~cm} 2$ then another object glass was placed on it. A weight of $1 \mathrm{~kg}$ was placed on top of the glass for five minutes. The time the attached object glass required to come off when given a weight of $80 \mathrm{~kg}$ was counted (Rahmawati and Setiawan, 2019).

Test animal treatment

This study has received ethical approval from the Research Ethics Committee of Universitas Ahmad Dahlan (No. 012003013). Sixteen test mice were evenly divided into four groups: positive control group receiving $10 \%$ povidone-iodine ointment, base control receiving gel base and two treatment groups whose incision wounds were treated with the gel base or free-range chicken egg white gels (10\% or $20 \%)$. The mice were first anesthetized using Topsy ointment and intramuscular ketamine injection at $100 \mathrm{mg} / \mathrm{kg} \mathrm{BW}$, then a midline dorsal incision about $1 \mathrm{~cm}$ long and $0.2 \mathrm{~cm}$ deep or until the subcutaneous layer was made. Povidone-iodine ointment and gels were applied to the incision site once a day at the same hour until the wound was healed. Throughout this time, the incision wound's length was measured once every other day using a caliper and observed for signs of wound repair macroscopically until the tenth day.

\section{Data Analysis}

The data collected throughout the experiment were processed statistically on the SPSS program. The analyses performed were the Shapiro-Wilk normality test, the Levene's homogeneity test, and the Kruskal Wallis test. A post hoc Mann-Whitney test was later performed at a 5\% significance level.

\section{RESULTS AND DISCUSSION}

Organoleptic properties

Gel preparations are required to pass necessary organoleptic tests, in which sensory characteristics like color, smell, shape, and texture are evaluated. Table 1 shows the organoleptic properties of the free-range chicken egg white gels formulated in this study. The higher the concentration of the egg whites used, the darker the color of the resulting gel. These gels are 
semisolid with a distinctive odor of egg whites. The gel base (carrier) used was Carbopol, without the addition of egg whites. The result of gel making is showed at Figure 1.

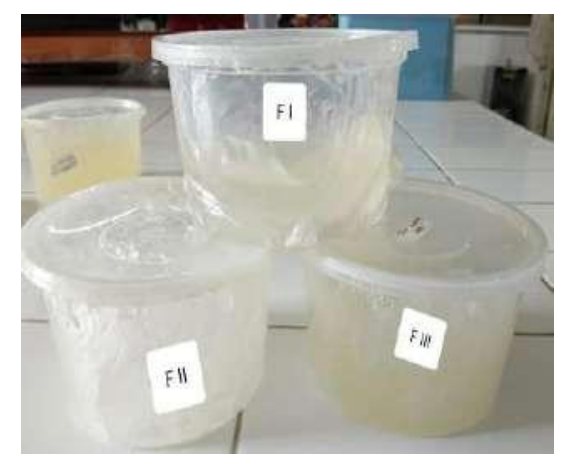

Figure 1. The free range chicken egg white gel preparation

Table 1. The organoleptic test results of the gel base and the free-range chicken egg white gels

\begin{tabular}{lllll}
\hline & Color & Odor & Shape & Texture \\
\hline Gel base & clear & Carbopol & semisolid & viscous, slightly \\
& & & & watery \\
$10 \%$ egg white gel & clear & egg white & semisolid & viscous \\
$20 \%$ egg white gel & $\begin{array}{l}\text { slightly } \\
\text { turbid }\end{array}$ & egg white & semisolid & viscous \\
& & & \\
\hline
\end{tabular}

In addition to organoleptic evaluation, the gels formulated from different egg white concentrations were also observed for their $\mathrm{pH}$ levels, spreadability, and adhesion. The results of these tests are summarized in Table 2 and described in detail in the following paragraphs.

Table 2. pH, spreadability, and adhesion evaluation results of the gel base and the free-range chicken egg white gels $(10 \%$ and $20 \%)$

\begin{tabular}{lccc}
\hline Gels & pH & $\begin{array}{c}\text { Spread Diameter } \\
(\mathbf{c m})\end{array}$ & $\begin{array}{c}\text { Adhesion Time } \\
\text { (minutes) }\end{array}$ \\
\hline Gel base & $6.00 \pm 0.00$ & $4.67 \pm 0.11$ & $0.38 \pm 0.10$ \\
10\% egg white gel & $6.00 \pm 0.00$ & $3.69 \pm 0.17$ & $7.04 \pm 0.54$ \\
$20 \%$ egg white gel & $6.00 \pm 0.00$ & $3.72 \pm 0.18$ & $6.04 \pm 0.42$ \\
\hline
\end{tabular}

\section{pH levels}

Based on the test results, the gel $\mathrm{pH}$ was 6 or within the accepted $\mathrm{pH}$ range for topical preparation, 4.5-6.5. Triethanolamine (TEA) was used in the formulation as a $\mathrm{pH}$-alkalizing agent to raise the $\mathrm{pH}$ so that the gel meets the $\mathrm{pH}$ characteristics of the skin. This type of dosage form should have a $\mathrm{pH}$ level similar to that of the skin. Otherwise, it can cause skin irritation (too acidic) and adverse effects like dry skin (too alkaline) (Nurman et al., 2019).

\section{Gel spreadability}

This test aims to determine a gel formulation that has good dispersion and the ideal quality for topical applications (Gabriela et al., 2016). According to (Garg et al., 2002), a gel preparation is categorized as semi-stiff if the spread diameter is less than $5 \mathrm{~cm}$ and semi-fluid if the spread 
diameter is between 5 and $7 \mathrm{~cm}$. A slightly watery gel creates a larger absorption diameter because it flows easily. Egg white gel has a viscous texture that hardly flows (Legros et al., 2021). Spreadability is highly sensitive to, among others, gel base characteristics and viscosity, and this also applies to the viscous free-range chicken egg white gel and its somewhat low spreadability. A lower viscosity means that a gel preparation has lower spread resistance so that it has relatively higher spreadability, and vice versa, a more viscous gel has higher resistance and, thus, lowered spreadability (Suryani et al., 2019). Therefore, the three gels formulated in this study are categorized as semi-stiff with an average spreadability of less than $5 \mathrm{~cm}$. Because a good-quality semisolid topical dosage form has spreadability in the range of 3-5 cm (Megawati et al., 2019), it is concluded that the gels prepared in this research meet this requirement.

\section{Adhesion capacity}

Adhesion indicates a gel's ability to adhere to the skin. A good-quality topical dosage form must have an adhesion capacity of not less than 4 seconds (Ulaen et al., 2012), and the adhesion test results in this research showed that the three gel formulas met this requirement. Adhesion also determines the duration and rate of drug absorption into the skin.

\section{Effects of free-range chicken egg white gel on wound-size reduction}

In this research, each incision wound on the mouse skin was observed macroscopically, and its length or size was also measured every day until signs of healing appeared, as indicated by a reduction in length and a slowly closing wound. Figure 2 shows the pictures of incision wounds of the four mouse groups seven days apart.

Table 3 present the average reductions in wound size in the positive control group and the three treatment groups. Overall, the incision wounds on the dorsal skin of the mice decreased in length. Group 3 (10\% free-range chicken egg white gel) showed the fastest wound repair, as indicated by the steep falling graph from day 1 to day 10 when the cuts began to heal (close).

The statistical analysis revealed a significant difference between the wound treatments with $10 \%$ gel and base gel $(\mathrm{p}<0.05)$. This result indicates that the $10 \%$ egg white gel has the best wound healing effect among the other groups, which may be attributed to the active substance that is easier to escape from this gel carrier and thereby allows faster penetration into the skin compared with $20 \%$ egg white gel. Furthermore, when the water-soluble albumin presents in larger quantities, it becomes more difficult for the active substance to separate from the base, which tends to be hydrophilic. Albumin is the body's predominant plasma protein (50-60\%) and greatly determines the regulation of osmotic pressure. The amount of albumin synthesized can vary according to clinical conditions (Utariani et al., 2020); to some extent, albumin can affect the production of cytokines and the expression of proteins and growth factors needed in wound healing (Utariani et al., 2021). 
A

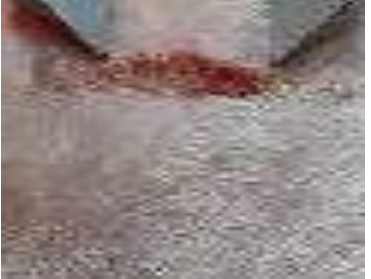

Positive control

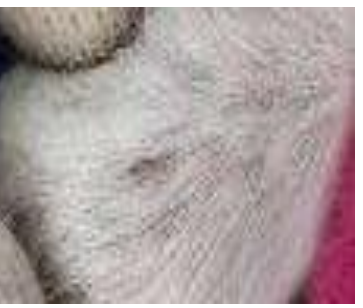

Positive control

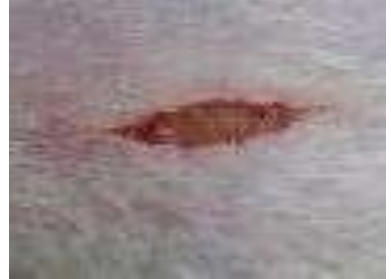

Base control

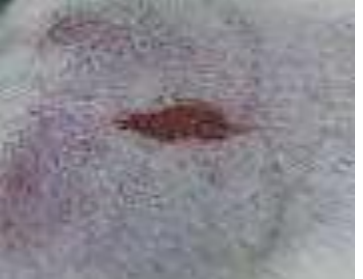

$10 \%$ chicken egg white gel

B

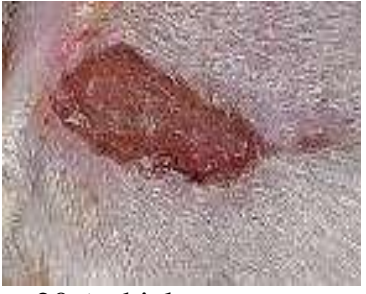

$20 \%$ chicken egg white gel

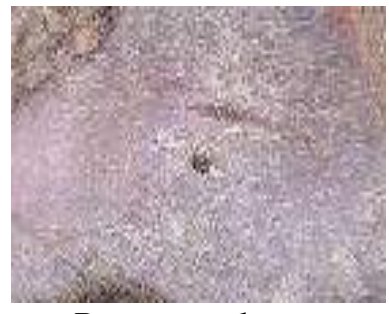

Base control

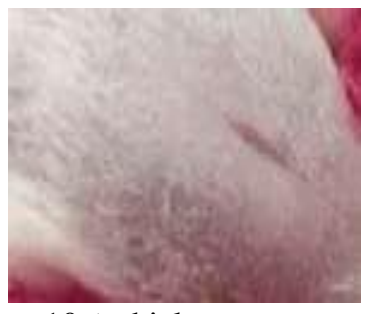

$10 \%$ chicken egg white gel

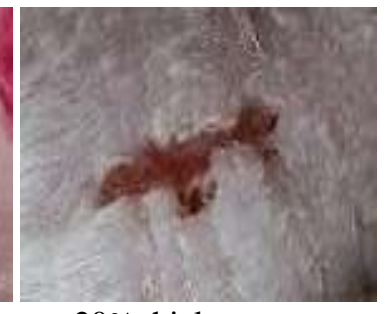

$20 \%$ chicken egg white gel

Figure 2. Macroscopic appearances of incision wounds on Day 1 (A) and Day 10 (B) On Day 1, the incision wound was red, long, and wide. On Day 8 , it begun toclose, as indicated by reduced wound size and hair grows around the shavedsite

Table 3. The average size ( \pm SD) of the incision wound based on the results of every-second-day measurements for ten days $(\mathrm{cm})$

\begin{tabular}{cccccc}
\hline Day $\boldsymbol{i}$ - th & $\mathrm{n}$ & $\begin{array}{c}\text { Positive control } \\
\text { (Povidon iodin) }\end{array}$ & $\begin{array}{l}\text { Base } \\
\text { control }\end{array}$ & $\begin{array}{l}\text { 10\% chicken } \\
\text { egg white gel }\end{array}$ & $\begin{array}{l}\text { 20\% chicken } \\
\text { egg white gel }\end{array}$ \\
\hline $\mathbf{2}$ & $\mathbf{4}$ & $\mathbf{0 . 8 6} \pm \mathbf{0 . 1 0}$ & $\mathbf{0 . 7 9} \pm \mathbf{0 . 1 0}$ & $\mathbf{0 . 7 9} \pm \mathbf{0 . 0 4}$ & $\mathbf{0 . 7 9} \pm \mathbf{0 . 0 6}$ \\
4 & 4 & $\mathbf{0 . 6 3} \pm \mathbf{0 . 0 9}$ & $\mathbf{0 . 6 3} \pm \mathbf{0 . 0 4}$ & $\mathbf{0 . 6 3} \pm \mathbf{0 . 0 3}$ & $\mathbf{0 . 6 1} \pm \mathbf{0 . 1 0}$ \\
6 & 4 & $\mathbf{0 . 4 1} \pm \mathbf{0 . 0 6}$ & $\mathbf{0 . 4 8} \pm \mathbf{0 . 0 9}$ & $\mathbf{0 . 4 6} \pm \mathbf{0 . 0 5}$ & $\mathbf{0 . 5 3} \pm \mathbf{0 . 0 7}$ \\
8 & 4 & $\mathbf{0 . 2 8} \pm \mathbf{0 . 2 1}$ & $\mathbf{0 . 3 3} \pm \mathbf{0 . 0 5}$ & $\mathbf{0 . 1 2} \pm \mathbf{0 . 1 4}$ & $\mathbf{0 . 3 3} \pm \mathbf{0 . 1 2}$ \\
$\mathbf{1 0}^{*}$ & 4 & $\mathbf{0 . 2 4} \pm \mathbf{0 . 2 2}$ & $\mathbf{0 . 3 1} \pm \mathbf{0 . 0 7}$ & $\mathbf{0 . 0 0} \pm \mathbf{0 . 0 0}$ & $\mathbf{0 . 2 0} \pm \mathbf{0 . 1 4}$ \\
\hline
\end{tabular}

Notes: ${ }^{x}$ marks $p<0.05$, i.e., significantly different from the base control group (gel carrier receiving group) at day 10

\section{Effects of free-range chicken egg white gel on wound healing}

Table 4 shows that group 3 (10\% egg white gel) has a significantly different healing time than groups 4 (20\% egg white gel) and 1 (gel carrier). This result indicates that applying a gel containing $10 \%$ free-range chicken egg white leads to faster wound repair than the one made with $20 \%$. The $20 \%$ egg white gel quickly dries and forms a rough crust (scab) over the wound area. However, cleaning or removing this blockage will create a new wound on the skin, causing bleeding that prolongs the inflammatory phase and inhibits new tissue generation and wound healing (Putrianirma et al., 2019). This argument corresponds to the theory proposed by (Simanjuntak, 2006), i.e., applying a preparation with high concentrations on a small wound surface causes a buildup of the preparation on the top layer of the membrane. As a result, there will be changes in the partition coefficient between the carrier and the skin barrier, making the active substance only partially released from the preparation and left on the surface. 
Table 4. The incision wound healing time of the four test groups

\begin{tabular}{lcc}
\hline \multicolumn{1}{c}{ Groups } & N & $\begin{array}{c}\text { Wound healing times (days) } \\
\text { mean } \pm \text { SD }\end{array}$ \\
\hline Positive control & 4 & $11 \pm 2.0$ \\
Base control & 4 & $13 \pm 1.1$ \\
$10 \%$ chicken egg white gel & 4 & $9 \pm 1.1^{\times}$ \\
$20 \%$ chicken egg white gel & 4 & $12.5 \pm 1.9$ \\
\hline Notes: ${ }^{*}$ marks $p<0.05$, i.e., significantly different from the base control group (gel carrier receiving group)
\end{tabular}

Group 2 exhibited the longest healing time. This is because the gel carrier applied has no active ingredient and a slightly watery texture, decreasing penetration into the skin and, thus, producing only slight effects on the wound healing process. Meanwhile, the incision wounds of group 4, treated with a gel containing $20 \%$ free-range chicken egg white, healed longer than those of group 3 that received a gel made with half of that concentration. In group 4, the wound did not immediately close because it was treated with a gel composed of a higher extract concentration that dried and formed a rough crust (scab) over it. Cleaning or removing this scab will create a new wound, causing bleeding that prolongs the inflammatory phase and inhibits the tissue remodeling phase of healing (Putrianirma et al., 2019).

Based on the healing time, spreading $10 \%$ egg white gel on the wound results in the shortest wound size on Day 10 and, therefore, the fastest incision wound healing among the tested groups. Basically, egg white possesses a pharmacological effect because of its albumin content. Albumin induces the expression of the epidermal growth factor receptor (EGFR) by activating extracellular signal-related kinase (ERK1/2) and upregulating nuclear factor kappa-light-chain-enhancer of activated B cells (NF-kB). EGFR plays an important role in the wound healing process through the stimulation of tyrosine kinase that activates gene transcription, DNA synthesis, and cell proliferation. EGFR also regulates the expression of transforming growth factor-beta (TGF- $\beta$ ), which is involved in several wound healing processes: inflammation, stimulation of angiogenesis, fibroblast proliferation, collagen synthesis, and deposition and remodeling of new extracellular matrix (Utariani et al., 2020). Albumin can stimulate the introduction of macrophages to induce phagocytosis that prevents infection and accelerates wound repair (Zhang et al., 2018). Egg white plays a role in forming and accelerating damaged cell tissue recovery; this function is attributable to albumin's abundant presence (95\%), which helps replace and repair damaged cell tissues (Purnani, 2019).

\section{CONCLUSION}

The free-range chicken egg white gel formulated in this research meets the physical requirements of a topical preparation. It has good spreadability and adhesion, and its $\mathrm{pH}$ is in the $\mathrm{pH}$ range of the skin. The $10 \%$ egg white gel can reduce wound length and speed up the healing process.

\section{ACKNOWLEDGMENT}

The authors would like to thank the Institute for Research and Community Services (Lembaga Penelitian dan Pengabdian Masyarakat, LPPM) for funding this study per the Research Agreement Letter No. PJB-010/SP3/LPPM-UAD/VI/2020.

\section{REFERENCES}

Danarti, R., Budiyanto, A., \& Wirohadidjojo, W. (2014). The effect povidone-iodine on the wound healing process : A study on fibroblast populated collagen lattice ( FPCL ) model. 46(3), 103107. https://doi.org/10.19106/JMedScie.004603201401 
Gabriela, M., Dantas, B., Alan, S., Bomfim, G., Mahara, C., Damasceno, D., Rolim, L. A., Rolimneto, P. J., Carvalho, F. O., Quintans-junior, L. J., Roberto, J., \& Almeida, S. (2016). Development and evaluation of stability of a gel formulation containing the monoterpene borneol. https://doi.org/10.1155/2016/7394685

Garg, A., Aggarwal, D., Garg, S., \& Singla, A. (2002). Spreading of semisolid formulations: An update. Pharmaceutical Technology, 26, 84-105.

Hendriati, L., Hamid, I. S., Widodo, T., Wandasari, C., \& Risata, P. M. (2018). Effect of egg white gel againts burn healing on white rat (Rattus novergicus). Jurnal Ilmu Kefarmasian Indonesia, 16(2), 231. https://doi.org/10.35814/jifi.v16i2.532

Legros, J., Jan, S., Bonnassie, S., Gautier, M., Croguennec, T., Cochet, M., Nau, F., \& Andrews, S. C. (2021). The role of ovotransferrin in egg-white antimicrobial activity: a review. https://doi.org/10.3390/foods10040823

Megawati, Roosevelt, A., \& Akhir, L. O. (2019). Formulasi dan uji stabilitas fisiksediaan gel ekstrak kulit buah rambutan (Nephelium lappaceum L.) sebagai obat sariawan menggunakan variasi konsentrasi basis karbopol. 5, 5-10

Nurman, S., Yulia, R., Noor, E., \& Sunarti, T. C. (2019). The optimization of gel preparations using the active compounds of arabica coffee ground nanoparticles. https://doi.org/10.3390/scipharm87040032

Percival, S. L. (2014). Wounds and infection. In Biofilms in Infection Prevention and Control. Elsevier Inc. https://doi.org/10.1016/B978-0-12-397043-5.00008-6

Purnani, W. T. (2019). Perbedaan efektivitas pemberian putih telur dan ikan gabus terhadap penyembuhan luka perineum ibu nifas. Journal of Public Health Research and Community Health Development, 2, 139-146. https://doi.org/10.1017/CBO9781107415324.004

Putrianirma, R., Triakoso, N., Yunita, M. N., Yudaniayanti, I. S., Hamid, I. S., \& Fikri, F. (2019). Efektivitas ekstrak daun afrika (Vernonia amygdalina) secara topikal untuk reepitelisasi penyembuhan luka insisi pada tikus putih (Rattus novergicus). Jurnal Medik Veteriner, 2(1), 30. https://doi.org/10.20473/jmv.vol2.iss1.2019.30-35

Rahmawati, D. A., \& Setiawan, I. (2019). The formulation and physical stability test of gel fruit strawberry extract (Fragaria x ananassa Duch.). 38-46.

Simanjuntak, M. . (2006). Biofarmasi sediaan yang diberikan melalui kulit.Universitas Sumatera Utara Sorg, J. M. R. H. (2012). Wound repair and regeneration. 35-43. https://doi.org/10.1159/000339613

Suryani, N., Mubarika, D. N., \& Komala, I. (2019). Pengembangan dan evaluasi stabilitas formulasi gel yang mengandung etil p -metoksisinamat. Pharmaceutical and Biomedical Sciences Journal, 1(November), 29-36.

Ulaen, S. P., Banne, Y., \& Suatan, R. A. (2012). Pembuatan salep anti jerawat dari ekstrak rimpang temulawak (Curcuma xanthorrhiza Roxb.). Jurnal Ilmiah Farmasi Poltekkes Manado, 3(2), 96587.

Utariani, A., Rahardjo, E., \& Perdanakusuma, D. S. (2020). Effects of albumin infusion on serum levels of albumin , proinflammatory cytokines ( TNF- $\alpha$, IL-1 , and IL-6 ), CRP , and MMP-8 ; Tissue Expression of EGRF, ERK1 , ERK2 , TGF- $\beta$, Collagen, and MMP-8; and wound healing in sprague dawley rats. https://doi.org/10.1155/2020/3254017

Utariani, A., Rahardjo, E., Perdanakusuma, D. S., Rehatta, N. M., Santoso, K. H., \& Semedi, B. P. (2021). The comparison effect between albumin infusion and normal protein diet on the acceleration of wound healing: a randomized control trial. 312-315. https://doi.org/10.5220/0008156403120315

Widjaya, H. A. (2016). Efektivitas gel putih telur pada penyembuhan luka insisi tikus putih (Rattus novergicus) melalui pengamatan penyembuhan luka dan sel makrofag. Widya Mandala Catholic University Surabaya.

Yao, K., \& Bae, L. (2013). Post-operative wound management. 42(12), 867-870. 
Zhang, Y., Wang, D., Smuda, K., Geogieva, R., Baumler, H., \& Gao, C. (2018). Inflammatory activation of human serum albumin- or ovalbumin-modified chitosan particles to macrophages and their immune response in human whole blood Yixian. Journal of Materials Chemistry B, 6 (19), 3096-3106. https://doi.org/10.1039/C7TB03096G 